\title{
Cytotoxic, genotoxic and apoptotic effects of Viburnum opulus on colon cancer cells: an in vitro study
}

\section{[Viburnum opulus'un kolon kanseri hücreleri üzerindeki sitotoksik, genotoksik ve apoptotik etkileri: Bir in vitro çalışma]}

https://doi.org/10.1515/tjb-2020-0182

Received May 3, 2020; accepted July 15, 2020; published online September 18, 2020

\section{Abstract}

Objective: Intake of various fruits is quite significant for maintaining the human body, due to their supply of useful constituents. $V$. opulus has been found to have outstanding antioxidant activity while showing a pro-oxidant effect at high doses. Due to this feature, $V$. opulus would be anticipated to have a healing impact on cancer treatment. In this study, it has been proposed to examine the cytotoxic, genotoxic, and apoptotic effects of $V$. opulus on human colorectal cancer cell.

Method: Different concentrations of $V$. opulus methanolic extract (5-2000 $\mu \mathrm{g} / \mathrm{mL}$ ) were incubated for $24 \mathrm{~h}$ with colorectal cancer cell line (Lovo). The cell viability, intracellular reactive oxygen species (iROS), DNA damage, and apoptosis were measured after incubation.

Results: The obtained results of this research demonstrate decreased cell viability and increased DNA damage, iROS,

Kubra Bozali and Eray Metin Guler are co-lead authors

*Corresponding author: Eray Metin Guler, Bezmialem Vakif University, Medicine Faculty, Department of Medical Biochemistry, Istanbul, Turkey, e-mail: eraymetinguler@gmail.com Kubra Bozali, Avans University of Applied Science, Biology and Medical Laboratory Research, Breda, the Netherlands Ahmet Sadik Gulgec, Bezmialem Vakif University, Pharmacy Faculty, Istanbul, Turkey

Abdurrahim Kocyigit, Bezmialem Vakif University, Medicine Faculty, Department of Medical Biochemistry, Istanbul, Turkey and apoptosis levels of $V$. opulus in Lovo cells in a concentration-dependent manner in the range of $14.88-$ $52.06 \%$. There were strong positive relationships between apoptosis, genotoxicity, and cytotoxicity in $V$. opulus methanolic extract treated cancer cell line.

Discussion: This in vitro research clearly demonstrated that $V$. opulus methanolic extract induces DNA damage, apoptosis, and cytotoxicity in a dose-dependent manner in cancer cells due to its pro-oxidant activity.

Conclusion: Although in vitro results are favorable, in vivo and further studies are needed.

Keywords: apoptosis; colorectal cancer; cytotoxicity; genotoxicity; Viburnum opulus.

\section{öz}

Amaç: Çeşitli meyvelerin tüketimi, büyük miktardaki fonksiyonel bileşenler aracılığıyla insan sağlığının korunması için oldukça önemlidir. V. opulus'un yüksek antioksidan aktiviteye sahip olduğunu göstermesine rağmen, bu bitki yüksek dozlarda pro-oksidan etki de göstermektedir. $\mathrm{Bu}$ özelliğinden dolayı $V$. opulus kanser tedavisi üzerinde iyileştirici bir etkisi olmaktadır. $\mathrm{Bu}$ çalışmanın amacı $V$. opulus'un kolon kanseri üzerindeki sitotoksik, genotoksik ve apoptotik etkilerinin incelenmesi önerilmiştir. Gereç ve yöntem: Farklı konsantrasyonlarda olan $V$. opulus metanolik ekstraktı (5-2000 $\mu \mathrm{g} / \mathrm{mL}$ ) kolorektal kanser hücre hattında (Lovo) 24 saat inkübe edilmiştir. İnkübasyondan sonra hücre canlılığı, hücre içi reaktif oksijen türleri (iROS), DNA hasarı ve apoptoz ölçülmüştür.

Bulgular: Bu çalışmanın elde edilen sonuçları, V. opulus ekstraktının kolorektal kanser hücre hattındaki (Lovo) 
hücre canlılığını azalttığını, DNA hasarını ve apoptoz düzeylerini doza bağımlı bir şekilde $\% 14.88$ ile $\% 52.06$ aralığında arttırdığını göstermiştir. $V$. opulus metanolik ekstrakt ile tedavi edilen kanser hücrelerinde DNA hasarı, apoptoz ile sitotoksisite arasında güçlü pozitif ilişsiler görülmektedir.

Tartıșma: $\mathrm{Bu}$ in vitro çalışma, V. opulus metanolik ekstraktının kanser hücrelerinde doza bağımlı bir şekilde prooksidan aktivitesi yoluyla apoptoz, DNA hasarı ve sitotoksisiteye neden olduğunu açık bir şekilde kanıtlamaktadır.

Sonuç: Her ne kadar in vitro sonuçlar iyi olsa da in vivo ve daha ileri çalışmalar gereklidir.

Anahtar Kelimeler: apoptoz; genotoksisite; Kolorektal kanser; sitotoksisite; Viburnum opulus.

\section{Introduction}

Colorectal cancer is a major global health issue. According to 2018 data published by the World Health Organization, colorectal cancer is the third most commonly diagnosed cancer following lung and breast cancers, while it takes second place in cancer deaths worldwide [1]. Diet and increased average life expectancy along with environmental factors increase the risk of colorectal cancer in humans in America and Europe, where it is industrially more developed. Age is the most critical risk factor in the development of sporadic colorectal cancer. The incidence begins to increase after age 45 , and almost $95 \%$ of the cases occur after 50 years of age [2].

Consuming a variety of fruits is quite important for an individual, as they contain significant amounts of functional constituents, suchlike total phenolic, and total antioxidant content, which are present in Viburnum opulus fruit [3]. $V$. opulus from the Caprifoliaceae family can be commonly observed grown naturally in Europe and sometimes also in Asia and North Africa [4]. The V. opulus fruit has a red color, an astringent bitter-sour taste, and is regarded as somewhat toxic due to the presence of saponin glycosides and viburnin [5]. The fruit of $V$. opulus is very acidic and contains a large number of polyphenols, ascorbic acid, and L-malic acid. The $V$. opulus fruits contain phenolic acids, such as hydroxybenzoic acids, tannins, coumarins, catechols, iridoid glycosides, anthocyanins, ascorbic acid, chlorogenic acid, salicin, (+)-catechin, (-)-epicatechin, cyanidin-3-glucoside, cyanidin3-rutinoside, and quercetin [6].

The purpose of this study is to investigate the effects of $V$. opulus methanolic extract on viability, DNA damage, intracellular reactive oxygen species (ROS), and apoptosis on human colon cancer cell. These potential properties are believed to be due to the phytochemical content of $V$. opulus, in particularly, the content of flavonoids, which appear to have high pro-oxidant activity.

\section{Material and methods}

\section{Chemicals}

ABTS (2,2'-Azino-bis (3-ethylbenzothiazoline-6-sulfonic acid) diammonium salt), methanol, DMSO (Dimethylsulphoxide) MTT (3-(4,5-dimethylthiazol-2-yl)-2,5-diphenyl tetrazolium bromide), Phosphate buffered saline, Folin-Ciocalteu, Ethidium bromide, Acridine orange, Ascorbic acid, Potassium acetate, Sodium acetate, Acetic acid, Gallic acid, Quercetin, $\mathrm{H}_{2} \mathrm{DCF}-\mathrm{DA}$, and Aluminum nitrate were purchased from Sigma-Aldrich, Merck, and Gibco.

\section{Plant extraction}

V. opulus fruits were collected from Bunyan, Kayseri, Turkey. $50 \mathrm{~g}$ pulp samples were extracted with $50 \mathrm{~mL}$ methanol at room temperature for $24 \mathrm{~h}$. Then the extract was centrifuged. After centrifugation, separated supernatants were evaporated at $45^{\circ} \mathrm{C}$ [7].

After evaporation, the extract was lyophilized. The extract was stored in an amber bottle at $-80^{\circ} \mathrm{C}$ until studies were conducted.

\section{Antioxidant assays}

Total antioxidant capacity (TAC): For the determination of the total antioxidant capacity of $V$. opulus, two reagents were used. The reagent 1 includes $0.4 \mathrm{M}$ sodium acetate buffer ( $\mathrm{pH}$ 5.8) and $0.4 \mathrm{M}$ acetic acid while reagent 2 includes $30 \mathrm{mM}$ acetate buffer (pH 3.6), $10 \mathrm{mM}$ ABTS, $\mathrm{H}_{2} \mathrm{O}_{2}$, and $10 \%$ ethylene glycol. $1 \mathrm{mM}$ ascorbic acid is used as the standard, diluted with Tris buffer. $10 \mu \mathrm{L}$ of the extract was mixed with reagent 1 and measured photometrically at $660 \mathrm{~nm}$. After measuring, $20 \mu \mathrm{L}$ of reagent 2 was added and incubated for $5 \mathrm{~min}$ at room temperature with a shaker. After this incubation process, the absorbances were measured spectrophotometrically at $660 \mathrm{~nm}$ [8].

Total polyphenol capacity: For the determination of the total polyphenol capacity of $V$. opulus extract, gallic acid was used as the standard. The extract samples were diluted with 1:1 PBS. $200 \mu \mathrm{L}$ of Folin-Ciocalteu reagent was added to $40 \mu \mathrm{L}$ of the extract, and the mixture was incubated at room temperature for $8 \mathrm{~min}$. After the incubation, $60 \mu \mathrm{L} 7.5 \% \mathrm{Na}_{2} \mathrm{CO}_{3}$ was added to the mixture. The solutions were incubated at $25{ }^{\circ} \mathrm{C}$ for $2 \mathrm{~h}$. The results of the sample were compared to gallic acid [9]. The absorbance of $V$. opulus extract was measured by spectrophotometry (Varioskan Flash Multimode Reader, Thermo, Waltham, USA) at $746 \mathrm{~nm}$.

Total flavonoid content: The content of total flavonoid was determined by spectrophotometry using quercetin as standard. V. opulus extract was mixed with methanol, $10 \%$ aluminum nitrate, $1 \mathrm{M}$ aqueous potassium acetate. The mixture was incubated at RT for $40 \mathrm{~min}$, then measured at $415 \mathrm{~nm}[10]$. 
CUPRAC: Cupric ion $\left(\mathrm{Cu}^{2+}\right)$ reducing capacities of $V$. opulus extract was applied by modifying the cupric ion reducing antioxidant capacity (CUPRAC) method by Apak [11]. Prepared extracts were dissolved in $10 \mathrm{~mL}$ ethanol. $20 \mu \mathrm{L}$ of these solutions were completed to $67 \mu \mathrm{L}$ with ethanol. The solutions were vortexed after adding $61 \mu \mathrm{L}$ of $10 \mathrm{mM} \mathrm{CuCl}_{2}$ solution, $61 \mu \mathrm{L}$ of $7.5 \mathrm{mM}$ neocuproine reagent, and $61 \mu \mathrm{L} \mathrm{NH}_{4} \mathrm{Ac}$ buffer ( $1 \mathrm{M}, \mathrm{pH}: 7$ ), and the solutions were incubated for $30 \mathrm{~min}$ at room temperature. After the incubation, the absorbance of the solutions was measured at $450 \mathrm{~nm}$ with the reference solution $1 \mathrm{mM}$ ascorbic acid.

\section{Cell line and treatment}

Colon cancer cell line Lovo (ATCC $₫$ CCL-229®) colorectal adenocarcinoma from human were grown in F12K medium, and 10\% Fetal bovine serum, and 1\% Penicillin-Streptomycin antibiotic. Adherent monolayer Lovo cells were incubated with saturated moisture in 5\% $\mathrm{CO}_{2}$ at $37^{\circ} \mathrm{C}$.

\section{Cytotoxicity}

The cytotoxic effects of $V$. opulus extract was determined by using in vitro MTT (3-(4,5 dimethylthiazol-2-yl)-2,5-diphenyltetrazolium bromide) assay [12]. Lovo cell line was cultured in a 96-well plate $\left(7 \times 10^{3}\right.$ cells $/ \mathrm{mL}$ ). After $24 \mathrm{~h}$ incubation, the medium was treated for $24 \mathrm{~h}$ with different concentrations of $V$. opulus $(5-2000 \mu \mathrm{g} / \mathrm{mL} ; \mathrm{l})$. After overnight incubation with the extract, the wells were treated with $15 \mu \mathrm{L}$ of $5 \mathrm{mg} / \mathrm{mL}$ MTT. This mixture was incubated for $4 \mathrm{~h}$ at $37^{\circ} \mathrm{C}$. After the incubation, $100 \mu \mathrm{L}$ of DMSO was added to each well and incubated at room temperature for $20 \mathrm{~min}$. After the incubation, the formed purple solution was quantified colorimetrically at $540 \mathrm{~nm}$ (Varioskan Flash Multimode Reader, Thermo, Waltham, USA).

To calculate the half-maximal inhibitory concentration $\left(\mathrm{IC}_{50}\right)$, the following formula has been used:

$$
\begin{aligned}
y & =a x+b \\
I C_{50} & =\frac{(0.5-b)}{a}
\end{aligned}
$$

\section{Intracellular reactive oxygen generation}

The level of intracellular reactive oxygen species was measured in fluorometry using $\mathrm{H}_{2}$ DCF-DA fluorescence dye. After different concentrations of $V$. opulus were incubated for $24 \mathrm{~h}$, the cells were washed three times with dPBS. The $5 \mu \mathrm{M} \mathrm{H}_{2} \mathrm{DCF}-\mathrm{DA}$ was incubated at $37^{\circ} \mathrm{C}$ for $30 \mathrm{~min}$ in the dark. After the incubation, the cells were washed and resuspended in dPBS. Intracellular ROS contents were measured using a fluorimeter (Varioskan Flash Multimode Reader, Thermo Scientific, USA).

\section{DNA damage}

The single-cell gel electrophoresis assay (Comet Assay) to evaluate the genotoxic effects of $V$. opulus extract on Lovo cells were performed with a minor modification to Singh et al. [13]. Lovo cells were seeded into 6-well plates to be incubated with different doses of $V$. opulus under $\mathrm{IC}_{50}$ for $24 \mathrm{~h}$. After incubation, the cells were removed with
trypsin-EDTA and centrifuged at $400 \times g$. Following the supernatant was aspirated, it was washed with $\mathrm{dPBS}$ at $400 \times \mathrm{g}$ for $5 \mathrm{~min}$.

Fifteen microliter of cell suspension was mixed with $85 \mu \mathrm{L}$ of $0.6 \%$ low melting agarose and added to the slide pre-coated with $1 \%$ normal melting agarose. After freezing the gel at $+4{ }^{\circ} \mathrm{C}$, it was incubated with lysis buffer at $+4^{\circ} \mathrm{C}$, and it was incubated for $40 \mathrm{~min}$ in the dark in an alkaline solution to unwind DNA in the presence of cooling. Slides were electrophoresed at $+4{ }^{\circ} \mathrm{C}$ for 25 min (condition: $26 \mathrm{~V}$, $300 \mathrm{~mA}$ ). Afterward, slides dehydrated with ethanol were stained with $2 \mu \mathrm{g} / \mathrm{mL}$ ethidium bromide, and images were recorded. All DNA figures were scored using the Comet assay IV software with a fluorescence microscope (Leica DM 1000, Solms, Germany).

\section{Apoptosis}

The nuclear morphological changes associated with apoptosis were analyzed by double staining $\mathrm{AO} / \mathrm{EB}$, as explained by McGahon et al. [14]. Lovo cells were seeded in the 6-well plate for $24 \mathrm{~h}$. The incubated cells were treated for $24 \mathrm{~h}$ at $37^{\circ} \mathrm{C}$ with $\mathrm{V}$. opulus concentrations below $\mathrm{IC}_{50}$, which was determined as a result of cytotoxicity assay. As a negative control, $1 \%$ DMSO was used. The cells were harvested and washed twice with PBS. The acridine orange/ethidium bromide solution was added to the cell suspension, and the nuclear morphology was evaluated by fluorescence microscopy (Leica DM 1000, Solms, Germany). Images were captured at randomly selected areas, and a minimum of 100 cells were counted. The inhibition rates of the concentrations were calculated with the formula as following:

$$
\text { Inhibition rate }=\left(\frac{\text { Number of deadce cells }}{\text { Number of total cells }}\right) \times 100
$$

\section{Statistical analysis}

All experiments in the study were performed a minimum of four times, and the results were given as mean \pm standard deviation (mean $\pm S D$ ). Statistical analyzes were made with one-way ANOVA. $p<0.05$ was considered statistically significant. The $\mathrm{IC}_{50}$ value of $V$. opulus was calculated by non-linear regression analysis. All statistical analysis of the study was done with the Statistical Package for Social Sciences (version: 23.0) program.

\section{Results}

\section{Phenolic content}

The quantification of the phenolic compounds content of the fruit from $V$. opulus methanol extract is shown in Figure 1. The concentrations of the extract that were determined are $1,2,4$, and $8 \mathrm{mg} / \mathrm{mL}$. The extracts were stated using the standard curve equation $y=0.0849 x+0.2424, R^{2}=0.9711$ in term of gallic acid equivalent. The amount of phenolic compounds ranged from 0.098 to $7.83 \mathrm{mg}$ gallic acid/mL $V$. opulus extract. 
Phenolic Content of Viburnum opulus

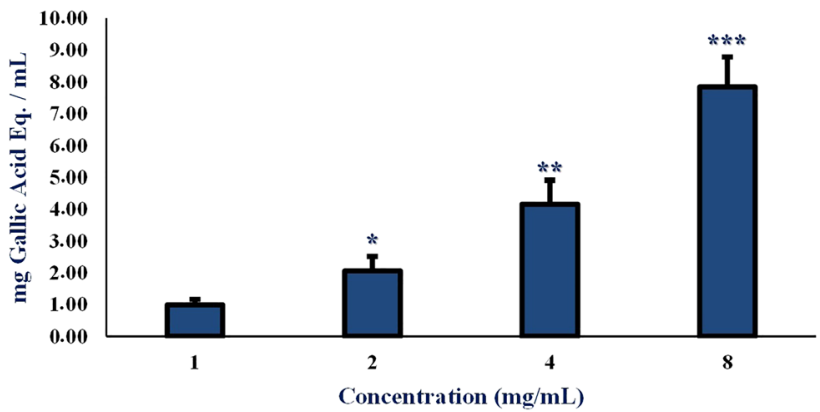

Figure 1: Phenolic content in Viburnum opulus concentrations is 1$8 \mathrm{mg} / \mathrm{mL}$. Statistically significant differences of compared to control; * for $p<0.05$, ** for $p<0.01$, *** for $p<0.001$.

\section{Flavonoid content}

Flavonoids are a large group of phenolic compounds among several important constituents of $V$. opulus fruit. The concentrations of the $V$. opulus methanol extract that were determined are $1,2,4$, and $8 \mathrm{mg} / \mathrm{mL}$. The extract was stated using standard curve equation $\mathrm{y}=0.314 \mathrm{x}-0.2084$, $\mathrm{r}^{2}=0.9773$ in term of quercetin equivalent. It can be seen in Figure 2 that the total flavonoid content of the extract is the dose-dependent manner in the range of $0.918-1.537 \mathrm{mg}$ quercetin/mL $V$. opulus methanol extract.

\section{Total antioxidant capacity}

With the ABTS method, the total antioxidant capacity of $V$. opulus methanol extract was detected. The concentrations of the extract that were determined are in the range of 1$8 \mathrm{mg} / \mathrm{mL}$. The extract was stated in term of ascorbic acid equivalent using a standard curve equation $y=-0.6425 x+0.6309, R^{2}=0.9939$.

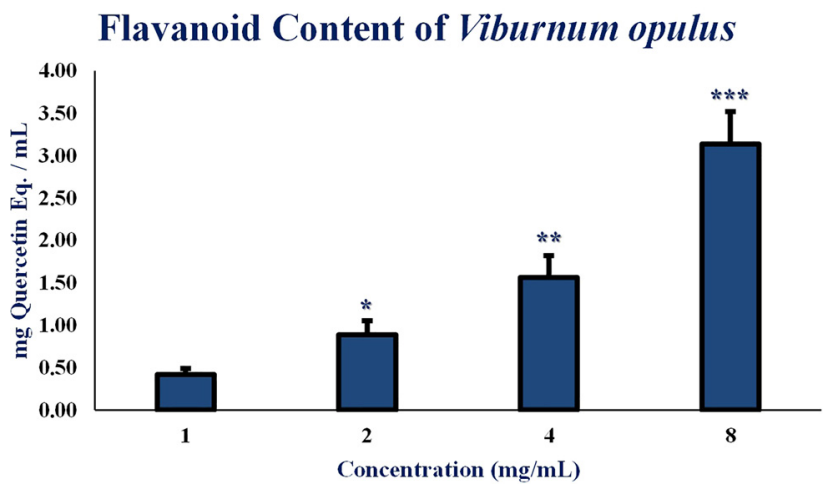

Figure 2: Flavonoid content of $V$. opulus concentrations is $1-8 \mathrm{mg} /$ $\mathrm{mL}$. Statistically significant differences of compared to control; * for $p<0.05,{ }^{\star *}$ for $p<0.01,{ }^{\star \star \star}$ for $p<0.001$.
Total Antioxidant Capacity

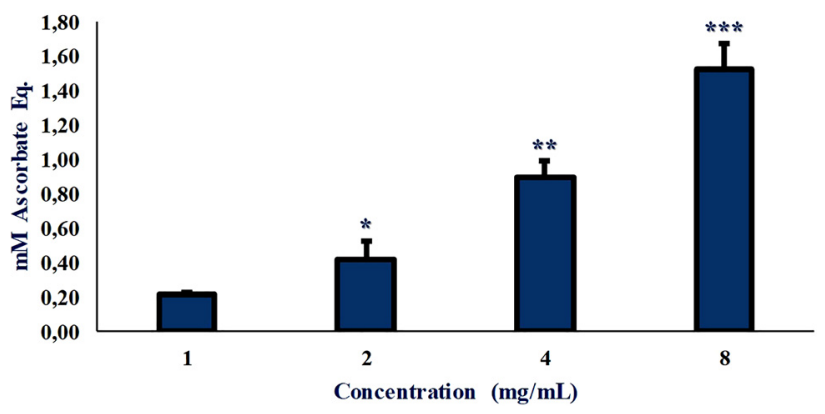

Figure 3: Total antioxidant capacity of $V$. opulus concentrations is 1-8 $\mathrm{mg} / \mathrm{mL}$. Statistically significant differences of compared to control; * for $p<0.05$, ** for $p<0.01$, *** for $p<0.001$.

The total antioxidant content of the extract ranged from 0.11 to $0.90 \mathrm{mmol} / \mathrm{L}$ ascorbic acid eq. (Figure 3).

\section{Cell viability}

To detect the cell viability, Lovo cells in the experiment were treated with increasing concentrations of $V$. opulus methanol extract $(5 ; 10 ; 50 ; 125 ; 250 ; 500 ; 750 ; 1000$; $2000 \mu \mathrm{g} / \mathrm{mL}$ ) for $24 \mathrm{~h}$. The control was without the extract treatment. After $24 \mathrm{~h}$, the cell viability was determined by MTT (3-(4,5-dimethylthiazol-2-yl)-2,5-diphenyltetrazolium bromide) assay.

Viability assay showed that the $V$. opulus methanol extract induced the cell viability in a concentrationdependent manner in the range of $5-2000 \mu \mathrm{g} / \mathrm{mL}$. The results of the cytotoxicity assay are presented in Figure 4. The extract was able to decrease the

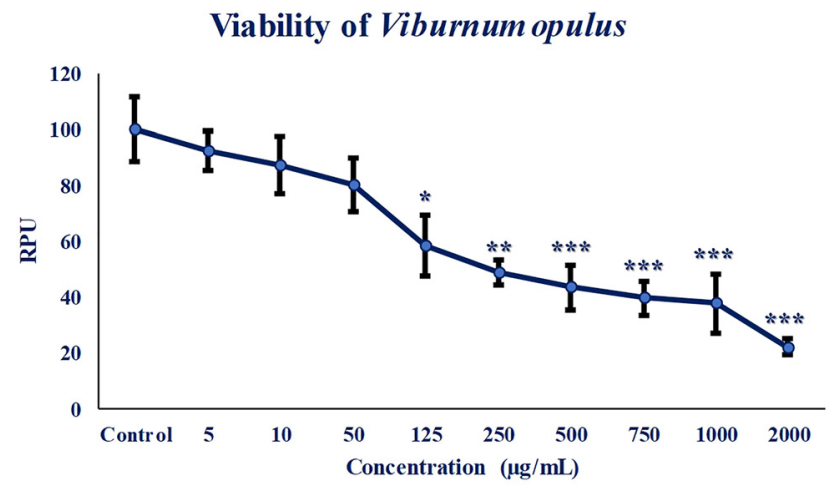

Figure 4: Effect of $V$. opulus on cell viability. Lovo cells were treated with concentrations $(5-2000 \mu \mathrm{g} / \mathrm{mL})$ of $V$. opulus for $24 \mathrm{~h}$. The calculated percent of cell cytotoxicity was normalized according to the control. All results are given as mean \pm standard deviation (mean \pm SD). Statistically significant differences of relative values compared to control; * for $p<0.05$, ** for $p<0.01$, *** for $p<0.001$. 
proliferation of Lovo cells. The $\mathrm{IC}_{50}$ of the extract is calculated with the standard curve equation $\mathrm{y}=-8.7575 \mathrm{x}+109.04$. The $\mathrm{IC}_{50}$ doses of $V$. opulus extract for Lovo cells were found $225.26 \mu \mathrm{g} / \mathrm{mL}$.

\section{Intracellular ROS generation}

The intracellular ROS generation was measured using the $\mathrm{H}_{2}$ DCF-DA probe by the fluorometric method. All doses (5$2000 \mu \mathrm{g} / \mathrm{mL}$ ) significantly reduced intracellular ROS production in Lovo cells (Figure 5).

\section{DNA damage}

The effect of different concentrations of $V$. opulus (below $\mathrm{IC}_{50}$ doses) in colon cancer cell on DNA damage after $24 \mathrm{~h}$ incubation was measured by the Comet Assay method. If there is no damage in DNA, round occurs, and if DNA is damaged, comet occurs (Figures 6, 7).

\section{Apoptosis}

The apoptotic effect of $V$. opulus methanol extract concentrations 10; 50; 100, and $200 \mu \mathrm{g} / \mathrm{mL}$ was detected by staining the cancer cell with acridine orange/ethidium bromide double dyes.

Figure 5 represents the results of acridine orange/ ethidium bromide staining as the percentage of apoptotic cells to total cells. The values are indicated as percentage mean of apoptotic cells to total cells in each dose point. The inhibition rate of the concentrations $10 ; 50 ; 100 ; 200 \mu \mathrm{g} / \mathrm{mL}$

\section{Intracellular ROS of Viburnum opulus}

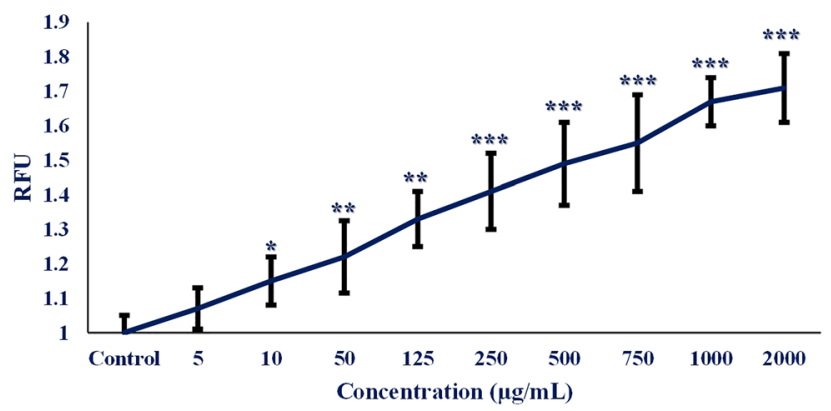

Figure 5: Effect of $V$. opulus on intracellular reactive oxygen species generation. Different concentrations of $V$. opulus were incubated in Lovo cells for $24 \mathrm{~h}$. The pro-oxidant activity of $V$. opulus was determined by using reactive oxygen generating assay. Statistically significant differences of relative values compared to control; * for $p<0.05,{ }^{* \star}$ for $p<0.01,{ }^{* \star *}$ for $p<0.001$.
DNA Damage effect of $V$. opulus

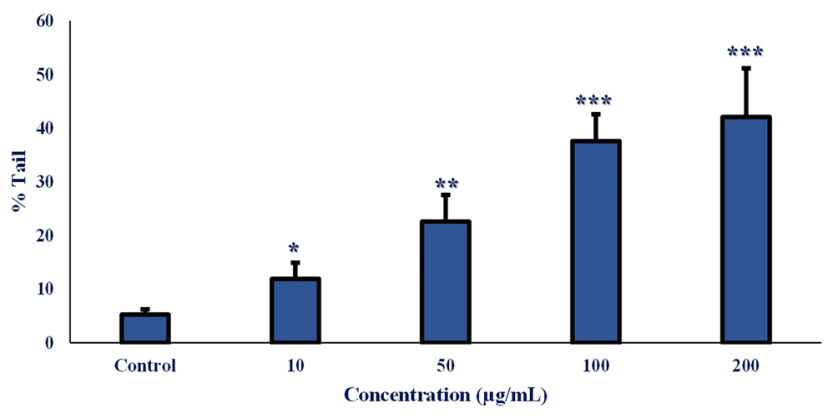

Figure 6: Lovo cells were treated with different concentrations of V. opulus ( 10 to $200 \mu \mathrm{g} / \mathrm{mL}$ ) for $24 \mathrm{~h}$. Statistically significant differences of relative values compared to control; * for $p<0.05$, ** for $p<0.01,{ }^{\star \star \star}$ for $p<0.001$.
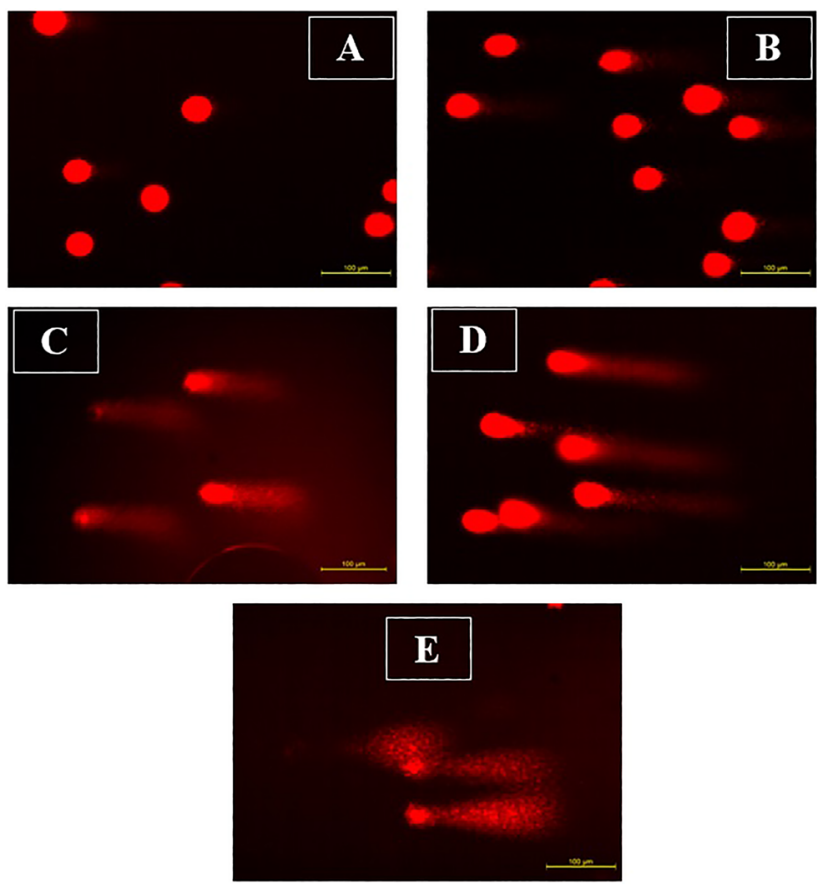

Figure 7: Increased $V$. opulus concentrations damaged the DNA of Lovo cells. Thus\% tail density increased statistically significantly. (A) Control without $V$. opulus treatment. (B) Treatment with $10 \mu \mathrm{g} / \mathrm{mL}$ $V$. opulus methanol extract. (C) Treatment with $50 \mu \mathrm{g} / \mathrm{mL} \mathrm{V}$. opulus methanol extract. (D) Treatment with $100 \mu \mathrm{g} / \mathrm{mL}$ V. opulus methanol extract. (E) Treatment with $200 \mu \mathrm{g} / \mathrm{mL} V$. opulus methanol extract under fluorescence microscope by 200X (Leica). Green color shows the normal morphology of living cells, while the yellow and orange color shows apoptotic cells.

are in the range of $14.88-52.06 \%$. The apoptosis-inducing potential of the extract was tested in cells using the acridine orange/ethidium bromide double staining assay. The morphology changes in apoptotic cells, including morphology change and nuclear fragmentation are shown 


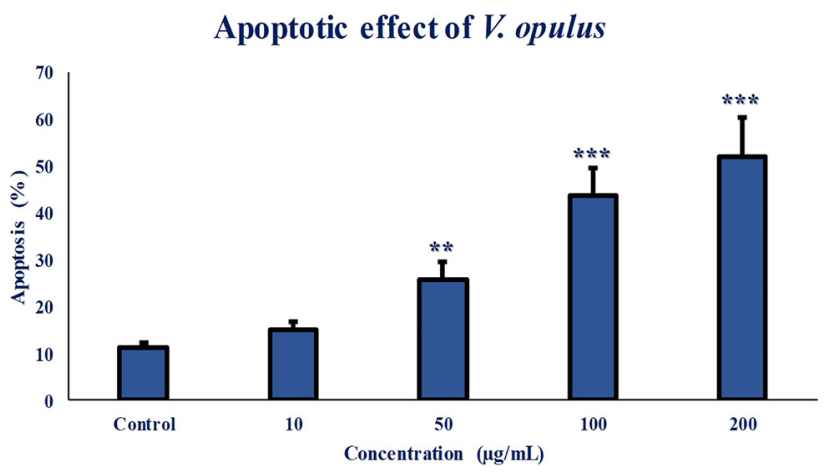

Figure 8: Effects of $V$. opulus on cell apoptosis in a colorectal cancer cell line (Lovo) treated with different concentrations (10; 100; 500; $1000 \mu \mathrm{g} / \mathrm{mL}$ ) of $V$. opulus extract for $24 \mathrm{~h}$.

in Figure 6. After the $24 \mathrm{~h}$ incubation, as the concentration of $V$. opulus increased, living cells decreased while apoptotic cells increased. These morphological changes of yellow-orange cells suggest that apoptosis increased in cells treated with $V$. opulus methanol extract in a dosedependent manner in the range of $14.88-52.06 \%$ in the Lovo cell line (Figures 8, 9).

\section{Discussion}

Colorectal cancer is a severe health problem in the world. In 2019 WHO data, death from colorectal cancer is the second in all cancer cases in the world [1]. The search for alternative treatments continues due to the inadequacy of the current drugs and combinations in the therapy of cancer. Antioxidants are found in natural diet, which include vitamins, carotenes, and minerals. Several antioxidants inhibit reactive oxygen compounds in metabolism. The positive effect of an antioxidant is to neutralize reactive oxygen species (ROS) and release it from the free radicals that may damage DNA and support tumorigenesis. The antioxidants are the first line of choice to take care of the stress $[15,16]$. The purpose of this research was to determine the amount of phenolic and flavonoid contents along with the antioxidant activity of $V$. opulus fruit methanol extract and to the purpose of the cytotoxic effects of the extract on human colon cancer cell line (Lovo) in culture. The antioxidative potential of $V$. opulus methanol extract was determined using photometric methods as well as phenolic and flavonoid content, total antioxidant capacity, and CUPRAC. The content of phenolic compounds was detected with gallic acid as the standard of $V$. opulus methanol extract in the range of $0.098-7.83 \mathrm{mg}$ gallic acid/ $\mathrm{mL}$. The total flavonoid content of the $V$. opulus methanol extract is in the range of $0.918-1.537 \mathrm{mg}$ quercetin $/ \mathrm{mL}$.
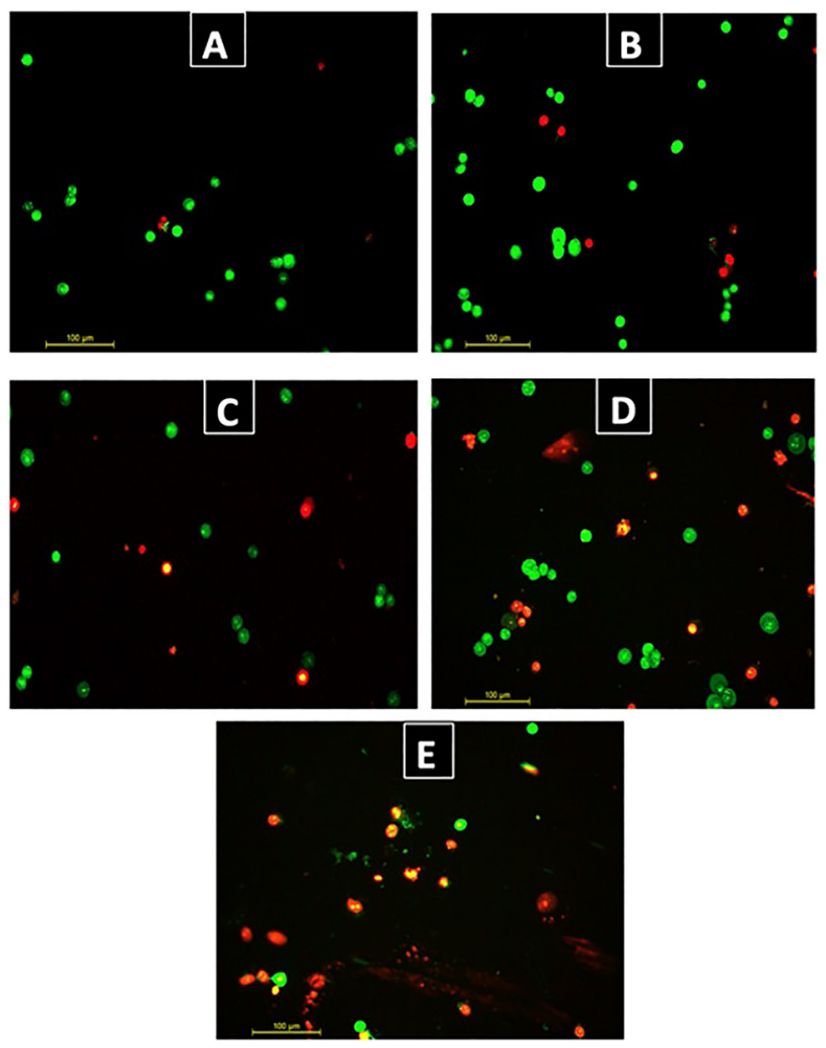

Figure 9: Acridine orange/ethidium bromide staining has shown a decreased apoptosis induced by stress in Lovo cell line treated with V. opulus methanol extract. (A) Control without V. opulus treatment.

(B) Treatment with $10 \mu \mathrm{g} / \mathrm{mL} V$. opulus methanol extract. (C) Treatment with $50 \mu \mathrm{g} / \mathrm{mL} V$. opulus methanol extract. (D) Treatment with $100 \mu \mathrm{g} / \mathrm{mL} V$. opulus methanol extract. (E) Treatment with $200 \mu \mathrm{g} / \mathrm{mL}$ V. opulus methanol extract under fluorescence microscope by 200X. Green color shows the normal morphology of living cells. It shows apoptosis in yellow and orange cells.

Judging by these findings, $V$. opulus can be classified rich in phenolic and flavonoid content. The total antioxidant content of the extract is in the range of $0.11-0.90 \mathrm{mmol} / \mathrm{L}$ ascorbic acid eq. The results showed that the concentration of the extract increased CUPRAC levels in a dosedependent manner in the range of $1.39-16.30 \mathrm{mmol} / \mathrm{L}$. The $\mathrm{IC}_{50}$ value of the extract was found $225.26 \mu \mathrm{g} / \mathrm{mL}$. This assay also confirmed the reduction on cell viability, and the decrease in cell number was due to the cytotoxic effects of $V$. opulus methanol extract against the colorectal cancer cell line. The cytotoxic effect of $V$. opulus may be derived from alkaloids, phenolic compounds, flavonoids, or their synergistic combinations that are found in $V$. opulus methanol extract. It is reported to play an important role of oxygen-derived radicals in the etiology of cancer development [5].

Previous studies in the literature have shown that V. opulus has no genotoxic activity [17]. But in our study, 
$V$. opulus has increasingly inflicted DNA damage as the dose increased. The most important difference between the literature and our study is that high doses of proxy effects cause DNA damage.

The apoptosis in this study was determined by the detection of acridine orange/ethidium bromide doublestained condensed nuclei by fluorescent microscopy. Apoptotic, necrotic, and live cells can be distinguished using acridine orange/ethidium bromide dye. While livinghealthy cells are green, the morphology of apoptotic cells has changed, and it is yellow-orange. Necrotic cells are colored red. Our results show that apoptosis and necrosis increase, and viability decreases between 5 and $2000 \mu \mathrm{g} /$ $\mathrm{mL}$ doses colorectal cancer cell in a concentrationdependent manner in the range of $14.88-52.06 \%$. Recent studies have shown that $V$. opulus has higher level of antioxidant activity and antimicrobial potency [18, 19]. From the other studies, the phenolic compound of the antioxidant content of $V$. opulus varied in the range of 5.4$10.6 \mathrm{mg} \mathrm{GAE} / \mathrm{g}$ [20]. Another study found total phenolic content as $351.26 \pm 27.73 \mathrm{mg} \mathrm{GAE} / 100 \mathrm{~mL}$ [15]. In our research, we found the phenolic content also in these ranges. V. opulus have antioxidant properties by low doses and pro-oxidant properties by high doses. Hence, V. opulus may have a positive effect on cancer treatment. $V$. opulus fruit extract modulates cell viability, cell proliferation, cell death, adhesion, inflammation, oxidative stress, and signal transduction pathways. $V$. opulus extract prepared with an organic solvent has a flavonoid-rich fraction and a total polyphenolic fraction, which inhibits the viability of colon cancer cell lines [21, 22]. In general, antioxidants inhibit oxidative damage due to their capability of inhibiting intracellular ROS. It should be noted, high doses of antioxidants show pro-oxidant activity with the presence of transition metals (iron-II and iron-III) [23]. To our knowledge, this study is the first in vitro study to show the pro-oxidant effects of $V$. opulus.

\section{Conclusion}

Intracellular ROS increased due to the high-dose prooxidant property of $V$. opulus extract. So, cytotoxicity, DNA damage, and apoptosis are increased. Experimental animals and clinical studies are needed for $V$. opulus to be an option in cancer treatment.

Acknowledgments: We thank to Dr. Muhammed Yunus Bektay, Dr. Mustafa Gokce, and the Republic of Turkey Ministry of Agriculture and Forestry Kayseri-Bunyan
Agriculture and Forestry Manager Mr. Zeki Buyuktanir for their support.

Research funding: None declared.

Author contributions: All authors have accepted responsibility for the entire content of this manuscript and approved its submission.

Competing interests: Authors state no conflict of interest. Informed consent: Informed consent was obtained from all individuals included in this study.

\section{References}

1. WHO. Cancer; 2020. Available from: https://www.who.int/newsroom/fact-sheets/detail/cancer [Accessed 25 April 2020].

2. Howe HL, Wingo PA, Thun MJ, Ries LA, Rosenberg HM, Feigal EG, et al. Annual report to the nation on the status of cancer (1973 through 1998), featuring cancers with recent increasing trends. J Natl Cancer Inst 2001;93:824-42.

3. Cesoniene L, Daubaras R, Viskelis P, Sarkinas A. Determination of the total phenolic and anthocyanin contents and antimicrobial activity of Viburnum opulus fruit juice. Plant Foods Hum Nutr 2012;67:256-61.

4. Konarska A, Domaciuk M. Differences in the fruit structure and the location and content of bioactive substances in Viburnum opulus and Viburnum lantana fruits. Protoplasma 2018;255:25-41.

5. Ceylan D, Aksoy A, Ertekin T, Yay AH, Nisari M, Karatoprak GS, et al. The effects of gilaburu (Viburnum opulus) juice on experimentally induced Ehrlich ascites tumor in mice. J Cancer Res Ther 2018;14:314-20.

6. Eken A, Yucel O, Bosgelmez I, Baldemir A, Cubuk S, Cermik A, et al. An investigation on protective effect of Viburnum opulus l. fruit extract against ischemia/reperfusion-induced oxidative stress after lung transplantation in rats. Kafkas Univ Vet Fak Derg 2017;23:437-44.

7. Kraujalis P, Kraujalienė V, Kazernavičiūtė R, Venskutonis PR. Supercritical carbon dioxide and pressurized liquid extraction of valuable ingredients from Viburnum opulus pomace and berries and evaluation of product characteristics. J Supercrit Fluids 2017; 122:99-108.

8. Erel O. A novel automated direct measurement method for total antioxidant capacity using a new generation, more stable ABTS radical cation. Clin Biochem 2004;37:277-85.

9. Ainsworth EA, Gillespie KM. Estimation of total phenolic content and other oxidation substrates in plant tissues using FolinCiocalteu reagent. Nat Protoc 2007;2:875-7.

10. Moreno MI, Isla MI, Sampietro AR, Vattuone MA. Comparison of the free radical-scavenging activity of propolis from several regions of Argentina. J Ethnopharmacol 2000;71:109-14.

11. Apak R, Guclu K, Ozyurek M, Esin Karademir S, Ercag E. The cupric ion reducing antioxidant capacity and polyphenolic content of some herbal teas. Int J Food Sci Nutr 2006;57:292-304.

12. Ferrari M, Fornasiero MC, Isetta AM. MTT colorimetric assay for testing macrophage cytotoxic activity in vitro. J Immunol Methods 1990;131:165-72.

13. Singh NP, McCoy MT, Tice RR, Schneider EL. A simple technique for quantitation of low levels of DNA damage in individual cells. Exp Cell Res 1988;175:184-91. 
14. McGahon AJ, Martin SJ, Bissonnette RP, Mahboubi A, Shi Y, Mogil RJ, et al. The end of the (cell) line: methods for the study of apoptosis in vitro. Methods Cell Biol 1995;46:153-85.

15. Koşar M, Orakçı E, Karatoprak GŞ. Antioxidant properties and phenolic composition of Viburnum opulus from Turkey. Planta Medica 2011;77:PL39.

16. Chu Y-F, Liu RH. Cranberries inhibit LDL oxidation and induce LDL receptor expression in hepatocytes. Life Sci 2005;77:1892-901.

17. Koparal A. In vitro evaluation of gilaburu (Viburnum opulus L.) juice on different cell lines. Anadolu J Educ Sci Int 2019;9: 549-71.

18. Sagdic O, Aksoy A, Ozkan G. Evaluation of the antibacterial and antioxidant potentials of cranberry (gilaburu, Viburnum opulus L.) fruit extract. Acta Alimentaria 2006;35:487-92.

19. Güleşci N. Viburnum opulus L.(Adoxaceae) Meyvesinin Antimikrobiyal, Antioksidan ve Kimyasal İçeriği Yönünden
Metabolizmaya Etkilerinin Değerlendirilmesi Üzerine Bir Derleme. IGUSABDER 2019;9:920-8.

20. Kraujalytė V, Venskutonis PR, Pukalskas A, Česonienè L, Daubaras R. Antioxidant properties and polyphenolic compositions of fruits from different European cranberrybush (Viburnum opulus L.) genotypes. Food chemistry 2013;141:3695-702.

21. Ulger $\mathrm{H}$, Ertekin $\mathrm{T}$, Karaca $\mathrm{O}$, Canoz $\mathrm{O}$, Nisari M, Unur E, et al. Influence of gilaburu (Viburnum opulus) juice on 1,2-dimethylhydrazine (DMH)-induced colon cancer. Toxicol Ind Health 2013;29:824-9.

22. Weh KM, Clarke J, Kresty LA. Cranberries and cancer: an update of preclinical studies evaluating the cancer inhibitory potential of cranberry and cranberry derived constituents. Antioxidants 2016; 5:27.

23. Azmi AS, Bhat SH, Hadi SM. Resveratrol-Cu(II) induced DNA breakage in human peripheral lymphocytes: implications for anticancer properties. FEBS Lett 2005;579:3131-5. 